Commentary

\title{
On being first in epidemiology
}

\author{
Steven D. Stellman
}

Department of Epidemiology, Mailman School of Public Health, Columbia University, 722 West 168th Street, New York, NY 10032, USA

"Be not the first by whom the New are try'd ..."Alexander Pope, Essay on Criticism

\begin{abstract}
"More I see of it, more this bein' first business looks funny ... I bet yo' twenty-five year from now some fat squirt or other will be braggin' his head off because he's the first white man to come through yere with a plug hat on." The Saga of Andy Burnett (White, 1947)
\end{abstract}

\section{"Who's on first?" Abbott and Costello, 1945}

In the past few years it has become the fashion for journal articles to proclaim their finding, however modest, to be first of its kind. Since few if any epidemiological studies are ever replicated down to the last detail, this form of self-advertisement is often less impressive than it appears. What, then, is the importance of establishing primacy for a particular epidemiological result such as the association between cigarette smoking and lung cancer? Should we even care who did it first?

Of course we should, for several reasons. As with all scientific disciplines, epidemiology has a history rich with useful and important lessons, but only a complete and accurate history can provide a satisfactory foundation on which to build a sound practice of public health. Careful study of our discipline's history provides a perspective that is otherwise easily overlooked or lost in the day-to-day pursuit of immediate research goals. Furthermore, we learn from mistakes as well as achievements, and there are plenty of both available for study.

At first glance, the relationship between cigarette smoking and lung cancer would seem an unlikely candidate for historical challenge. It is so well established that one or another aspect is routinely used as textbook and teaching material (Gordis, 2009). Furthermore, the founders of the field - e.g., Ernst Wynder, Sir Richard Doll, Austin Bradford Hill, and Cuyler Hammond - are so well known and their papers and books so widely reproduced and studied that controversy regarding the early days scarcely seems possible.

In this issue of Preventive Medicine Alfredo Morabia (Morabia, 2012) dissects a paper (Müller, 1939) that has been described by later historians and researchers as pathbreaking or seminal

E-mail address: sds91@columbia.edu. (e.g., Kluger, 1996; Proctor, 2011; USDHHS 1964). In the process, he finds it methodologically weak even by the standards of its day, and not even the first paper. Did the historians get it wrong, and if so, why?

For one thing, professional historians of tobacco and health do what they do best, namely, ferret out interrelationships, hidden agendas, and corporate greed and misconduct, against a broad backdrop of scientific advances in chemistry and toxicology as well as epidemiology. In uncovering and synthesizing thousands of facts into a comprehensive story, they often take reported epidemiological findings at face value and rarely discuss methodological strengths and weaknesses at the depth of, say, a grant or manuscript review. They are adept at exposing industry sponsored studies that were purposefully designed to miss the point or fail completely, but may not be sensitive to a study's deeper problems. Morabia, by contrast, a practicing epidemiologist with an international reputation who also possesses impressive credentials in the history of epidemiology (Morabia, 2004) is in a unique position to critique Müller's study from both a historical and a design perspective.

What lessons can we learn from Morabia's critique? Not surprisingly, lessons that are relevant to modern studies. First, there is the problem of study design. Müller's study is often described as the first case-control study of smoking and lung cancer. Morabia argues that it is merely a large case series. This is not a mere quibble over terminology: if correct, there is little basis for assessing the strength of association between smoking and lung cancer from Müller's data. Secondly, there is the unproved but dark suggestion of two varieties of manufactured data: daily consumption of tobacco deduced from data provided by a proxy respondent or perhaps not at all, and conversion of stated consumption to grams smoked per day. Inventing data, of course, if it happened, is by far the larger sin, but the practice of reporting the weight of tobacco smoked daily, common in France (Tuyns et al., 1977) as well as Germany, can produce a false illusion of accurate measurement. It is doubtful whether any of Müller's smokers knew to the gram how much they smoked per day. More likely, Müller simply multiplied the number of cigarettes smoked per day by an assumed average tobacco content. We do not know the variability of German cigarette weight 75 years ago, but, as Morabia points out, the weight of tobacco in a modern American cigarette can vary by as much as 50\% (0.49-0.89 g) (Counts et al., 2004) and quality control processes in the 1920s and '30s are unlikely to have been nearly as good as those of modern-day cigarette producers. Third, although there is no a priori reason to challenge the 30-50 


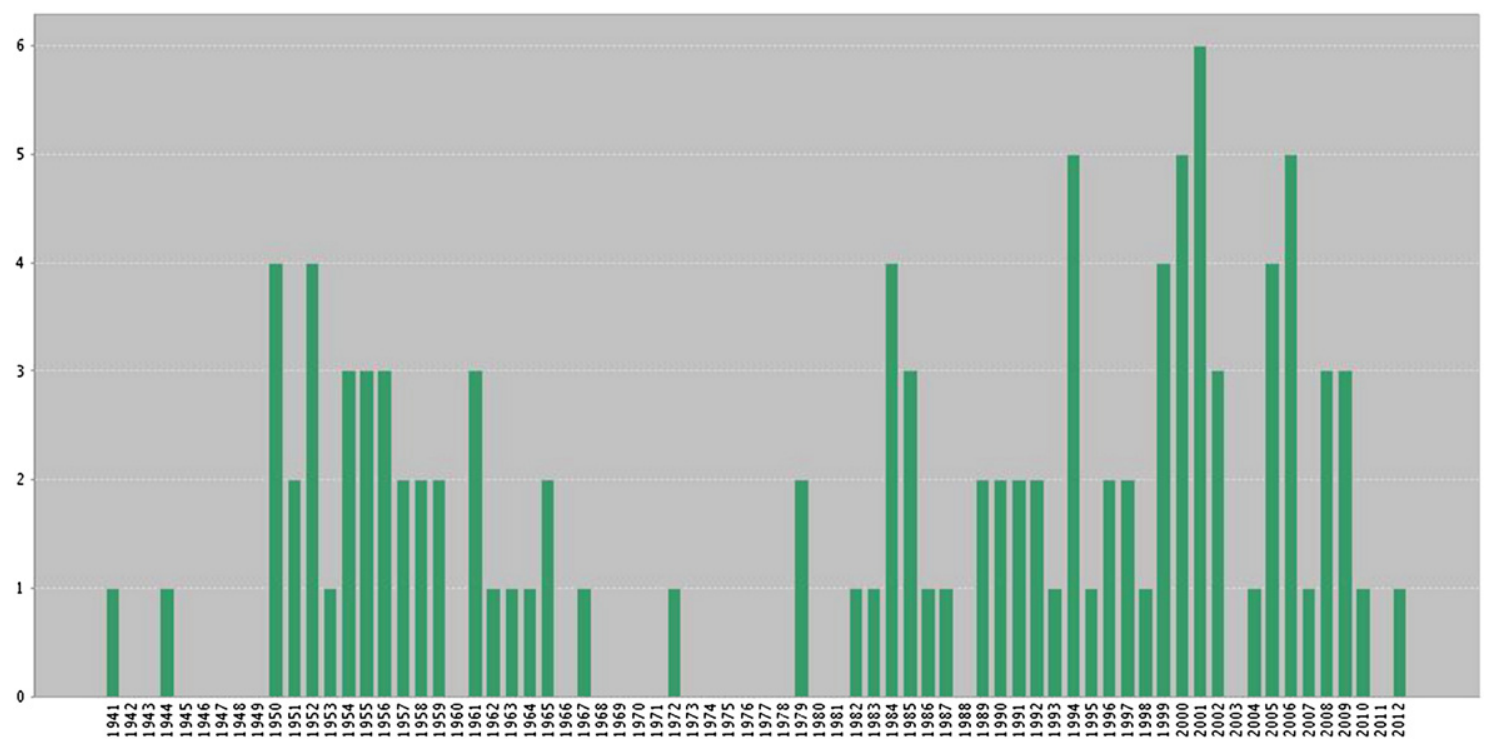

Fig. 1. Yearly citation count for Müller's (1939) paper. Source: Web of Knowledge@.

cigarettes per day attributed by Müller to his study subjects, this would imply a nicotine dosage as high as $135 \mathrm{mg} /$ day based on mid-1950s machine yields (Hoffmann and Hoffmann, 1997). This is more than twice the estimated nicotine dosage of $51 \mathrm{mg} /$ day inhaled by an American smoker of 50 Marlboro $100 \mathrm{~mm}$ filter cigarettes per day (Counts et al., 2004), and over three times the nicotine intake measured topographically in our American Health Foundation studies of smokers of medium-yield cigarettes (Djordjevic et al., 2000). That would be quite a buzz for many smokers.

Finally there is the issue of primacy itself. There is an old dictum in mathematics that a single counter-example can invalidate a theorem. By identifying the study of Hoffman (1931) that clearly predates Müller, Morabia has made a strong case, although Samet, in an accompanying commentary, raises some doubts (Samet, 2012).

History is our collective professional narrative that helps us sort and organize the countless facts that are the raw data of our professional lives. Determining whether Müller's study was "the first" is a necessary step towards historical accuracy, but even more important is development of an agreed-upon narrative that establishes individual historical facts as the foundation on which public health principles are built. Most important, however, is how its subsequent impact on public health evolved. Müller's one paper of importance, published on the eve of World War II, was picked up by JAMA which in that era summarized noteworthy papers that had been published in both domestic and foreign medical journals (Anonymous, 1939). It was first cited in a 1941 paper on tobacco carcinogenesis in the very first volume of Cancer Research (Flory, 1941), and then, remarkably, in a 1944 German paper on experimental carcinogenesis (Sjolte, 1944). It re-emerged in the 1950 classic papers by Doll and Hill (1950) and Wynder and Graham (1950), and then in a cluster of papers during the 1950s and early 1960s (Fig. 1). It disappeared for a while, then re-emerged in the 1980s and has been cited about twice a year since then a total of 108 times according to the Web of Knowledge $($. Müller, a Nazi, seems to have disappeared into the chasm of World War II, and his personal influence on public health is limited to this one publication. Sir Richard Doll, of course, became an iconic figure in epidemiology as detailed in a recent biography (Keating, 2009), while Wynder, whose 800 or so papers have been cited in nearly
30,000 publications (Stellman, 2006a), went on to found the American Health Foundation as well as this Journal (Stellman, 2006b).

\section{Conflict of interest statemen}

The author declares that there are no conflicts of interest.

\section{References}

Anonymous, 1939. Abuse of tobacco and carconima of lungs [extended abstract]. J. Am. Med. Assoc. 113, 1372

Counts, M.E., Hsu, F.S., Laffoon, S.W., Dwyer, R.W., Cox, R.H., 2004. Mainstream smoke constituent yields and predicting relationships from a worldwide market sample of cigarette brands: ISO smoking conditions. Regul. Toxicol. Pharmacol. 39, 111-134.

Djordjevic, M.V., Stellman, S.D., Zang, E., 2000. Doses of nicotine and lung carcinogens delivered to cigarette smokers. J. Natl. Cancer Inst. 92, 106-111.

Doll, R., Hill, A.B., 1950. Smoking and carcinoma of the lung; preliminary report Br. Med. J. 2, 739-748.

Flory, C.M., 1941. The production of tumors by tobacco tars. Cancer Res. 1, 262-276.

Gordis, L., 2009. Epidemiology, 4th ed. Saunders, Philadelphia.

Hoffman, F.L., 1931. Cancer and smoking habits. Ann. Surg. 93, 50-67.

Hoffmann, D., Hoffmann, I., 1997. The changing cigarette, 1950-1995. J. Toxicol Environ. Health 50, 307-364.

Keating, C., 2009. Smoking Kills: The Revolutionary Life of Richard Doll. Signal Books, Ltd., Oxford, UK.

Kluger, R., 1996. Ashes to Ashes: America's Hundred-year Cigarette War, the Public Health, and the Unabashed Triumph of Philip Morris. Alfred A. Knopf, New York.

Morabia, A., 2004. A History of Epidemiologic Methods and Concepts. Birkhaüser Verlag, Basel.

Morabia, A., 2012. Quality, originality, and significance of the 1939 "tobacco consumption and lung carcinoma" article by Müller, including translation of a section of the paper. Prev. Med. 55, 171-177.

Müller, F., 1939. Tabakmißbrauch und lungenkarcinom. Z. Krebsforsch. 49, 57-85.

Proctor, R.N., 2011. Golden Holocaust: Origins of the Cigarette Catastrophe and the Case for Abolition. University of California Press, Berkeley, CA.

Samet, J.M., 2012. What was the first epidemiological study of smoking and lung cancer? Prev. Med. 55, 178-180.

Sjolte, I.P., 1944. Primäre maligne Tumoren der Lungen bei Tieren Carcinoma et Carcino-Sarcoma pulmonum primum. Virchows Arch. Pathol. Anat. Physiol. Klin. Med. 312, 35-63.

Stellman, S.D., 2006a. Ernst Wynder: citation analysis. Prev. Med. 43, 268-270.

Stellman, S.D., 2006b. Ernst Wynder: a remembrance. Prev. Med. 43, 239-245.

Tuyns, A.J., Péquignot, G., Jensen, O.M., 1977. Le cancer de l'œsophage en Ille-et-Vilaine en fonction des niveaux de consommationd'alcool et de tabac - Des risques qui se multiplient. Bull. Cancer 64, 45-60.

USDHHS, 1964. Smoking and Health: Report of the Advisory Committee to the Surgeon General of the Public Health Service, 1964. USDHHS, Washington, DC.

White, S.E., 1947. The Saga of Andy Burnett. Doubleday and Company, New York

Wynder, E.L., Graham, E.A., 1950. Tobacco smoking as a possible etiologic factor in bronchiogenic carcinoma - a study of 684 proved cases. J. Am. Med. Assoc. 143, 329-336. 